\title{
腰椎後縦靯帯骨化の臨床的検討
}

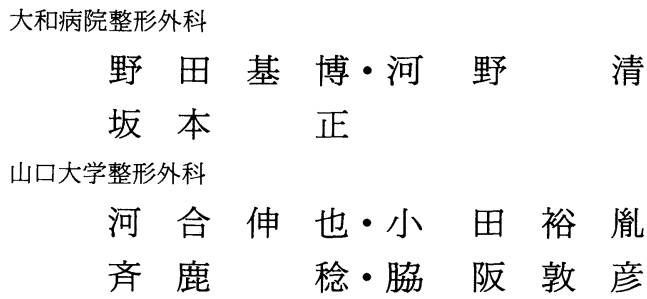

\section{A Clinical Study on Ossification of the Posterior Longitudinal Ligament of the Lumbar Spine}

by

\author{
Motohiro Noda, Kiyoshi Kawano and Tadashi Sakamoto \\ Section of Orthopaedic Surgery Hospital of Yamato \\ Shinya Kawai, Hirotsugu Oda, Minoru Saika \\ and Atsuhiko Wakisaka \\ Department of Orthopaedic Surgery, \\ Yamaguchi University School of Medicine
}

\begin{abstract}
OPLL of the lumbar spine have been reported less than that of the cervical spine. OPLL leads to one of the causative factors of canal stenosis, but it is low incidence that the patients develop symptoms due to OPLL. We studied clinically 8 patients who had OPLL of the lumbar spine with low back pain, lower limb pain, sensory disturbance, and/or intermittent claudication. Five cases were male and three were female with the age range from 35 to 65 years old (average, 52 years). We diagnosed clinically and radiologically 5 of them as OPLL and the other as lumbar disc herniation. To assess the symptoms due to OPLL, we attempted to compare with the former g-roup and the latter group. In spite of their existence of OPLL, it may or may not have clinical symptoms and signs, so careful attention must be taken to observe the condition.
\end{abstract}

はじめに

腰椎後縦靯帯骨化は，頝椎部に比し頻度が少なく， 脊柱管狭窄症の一因となっても後縦勒帯骨化のみで発 症することは少ない. 今回われわれは, 腰痛, 下肢痛, 下肢しびれ感, 間歇性跛行などを訴え, X線上腰椎後 縦勒帯骨化を認めた 8 例について臨床的検討を行った ので報告する。

対象および方法

対象は, 男性 5 例，女性 3 例の計 8 症例で年令は,
35 才〜 65 才（平均 51 才）であった。

自・他覚所見と myelogram, CT, tomogram, 選択 的神経根ブロックなどの補助的検查所見から, 腰椎後 縦勒带骨化症 5 例, 腰椎椎間板へルニア 3 例と診断し た。この 2 群について，X線学的，臨床的に比較検討 を行った。

結果

後綎䩲帯骨化の形態は, いずれも限局型で高位とし ては, 胸腰椎移行部から下位腰椎にかけて広く分布し ており, 後縦勒帯骨化が 1 椎間 のみに存在したものは, 
2 例のみで, 他の 6 例では, 多椎間に存在していた(図 1 ).

まず, 腰椎後縦靱带骨化症 5 例についてみると, 腰 痛, 歩行障害, 下肢異常知覚を全例に認め, この他, 間歇性跛行を 2 例に, 大腿筋萎縮を 2 例に, drop foot を 1 例に認め, いわゆる ${ }^{2)}$ 腰部春柱管狭窄症の症状を呈 していた（表 1 ）。そのうち 4 例（症例 $1 \sim 4$ ）では, 保存的治療で効果なく, 観血的治療を, 施行したとこ ろ, 症状は, , 著明な改善を, 示した. 採用した術式は, 広い視野で, 後縦䩲帯骨化を摘出し, かつ椎弓の還納 が, 可能であり後方要素の温存が期待できる ${ }^{1) 314)}$. 腰椎 椎管拡大術を採用した。

術中所見は，いわゆる degenerative LCS と異なり， 黄色靱帯, 椎間関節などの, 後方要素は, 比較的健常 であった，硬膜管前方の骨化巣は，椎間板高位で幅広 く存在し, 硬膜管と神経根を強く圧排, 癒着していた。 他の 1 例（症例 5 ）は, 神経症状も軽く, 保存的療法

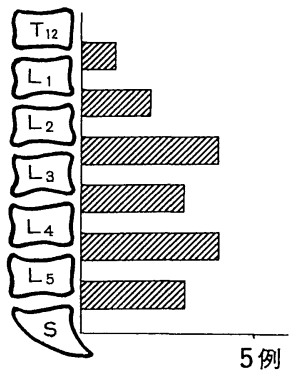

図 1 高位別頻度（延数）

表 1 腰椎後縦䩲带骨化症（5 例）

\begin{tabular}{|c|c|c|c|c|c|}
\hline 症例 & $\begin{array}{l}\text { 年令 } \\
\text { (才) }\end{array}$ & 性 & OPLL & 運動障害 & 異常知覚 \\
\hline 1 & 43 & 男 & $\mathrm{L}_{2^{-}}{ }_{3}$ & $\begin{array}{l}\text { 大腿 } ・ \text { 下腿筋 } \\
\text { 萎縮 } \\
(\text { (右) }\end{array}$ & $\begin{array}{l}\mathrm{L}_{3-} \mathrm{S}_{1} \\
\text { (両側) }\end{array}$ \\
\hline 2 & 35 & 男 & $\begin{array}{ll}\mathrm{L}_{1-2}, & 2-3 \\
3-4, & 4-5 \\
5-\mathrm{S}_{1}\end{array}$ & 下垂足（左） & $\begin{array}{c}\mathrm{L}_{4}-\mathrm{S}_{1} \\
\text { (左) }\end{array}$ \\
\hline 3 & 54 & 女 & $\begin{array}{l}\mathrm{L}_{4-5} \\
\mathrm{~L}_{5-\mathrm{S}_{1}}\end{array}$ & $\begin{array}{r}\text { 間歇性跛行 } \\
(\text { 右) }\end{array}$ & $\begin{array}{l}\mathrm{L}_{5-\mathrm{S}} \mathrm{S}_{1} \\
\text { (右) }\end{array}$ \\
\hline 4 & 49 & 女 & $\begin{array}{r}\mathrm{L}_{2-3} \\
3-4 \\
4-5\end{array}$ & $\begin{array}{r}\text { 間歇性跛行 } \\
(\text { 左) }\end{array}$ & $\begin{array}{r}\mathrm{L}_{3-5} \\
\text { (左) }\end{array}$ \\
\hline 5 & 49 & 女 & $\begin{array}{l}\mathrm{T}_{12-} \mathrm{L}_{1} \\
\mathrm{~L}_{1-2}\end{array}$ & $\begin{array}{c}\text { 大腿 筋 萎 縮 } \\
\text { (両側) }\end{array}$ & $\begin{array}{l}\mathrm{L}_{2-5} \\
\text { (両側) }\end{array}$ \\
\hline
\end{tabular}
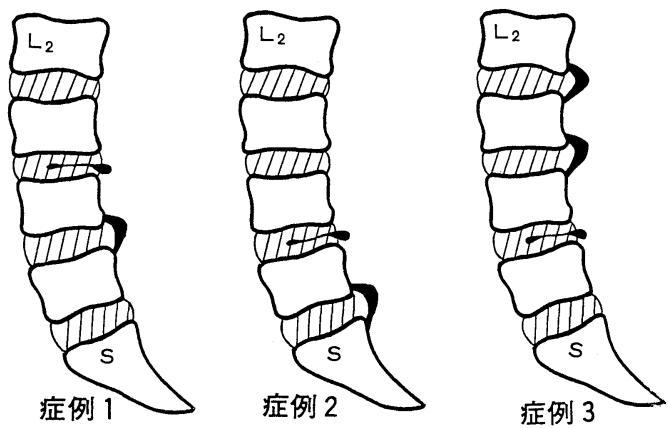

図 2 腰椎々間板ヘルニア例（3 例）

にて改善したため，現在経過観察中である.

次に, 腰椎椎間板ヘルニア 3 例についてみると, 比 較的急激に発症した腰痛, 下肢放散痛が特徵的で, 後 縦靯帯骨化の程度は, 前者に比し軽度であった。ヘル ニア高位は， 2 例は後緃勒帯骨化を認めた隣接上位椎 間に, 1 例は, 2 椎間に存在する後縦靯帯骨化の隣接 下位椎間にみられた (図 2 ). 神経学的所見や諸検查に て, 障害は椎間板へルニアによるものと考え, 後緃靯 帯骨化の関与は, きわめて乏しいと判断して love 法に 準じヘルニアの摘出のみを施行したところ, 症状は全 例に著明に改善した。

\section{考察}

後縦靯带骨化は, 脊柱管を前方から狭窄させ, 脊髄 の圧迫症状を呈するが, 腰椎部ではその解剖学的特徵 より,一般にはかなりの狭窄率を呈して, はじめて発 症すると思われる。

このことは, 後縦靯帯骨化症の 5 例において最狭窄 部位での狭窄率が 20～ $50 \%$ （平均 $32 \%$ ）であったの に対し，椎間板ヘルニア例では，狭窄率は，15～29\% (平均 $20 \%$ ) であり, 明らかに後縦䩲帯骨化症群に狭 窄率が高く, 狭窄率 20 ～ $30 \%$ が 1 つの critical level と も考えられた。

手術所見では, 後綐靱帯骨化は椎間板高位に位置し ており, 弧状に肥厚し側方に伸びて椎間孔に達し，そ こで神経根を圧排, 絞扼しており, 部位によっては, 骨化巣が神経根をとり巻いている所見を観察した。す なわち，神経根は後䋛勒帯骨化により高度に圧排を受 けており，その結果症状を呈したものと考えた。しか しながら, 後縦靯帯の摘出を行った 9 椎間について, 神経根の状態を比較すると，4椎間 $(44 \%$ ）では，む 
しろ症状を呈していない側の圧排，癒着所見が強く認 められており, 狭窄の程度と発症が, 必ずしも一致し ないこともあり注目に值する。

腰椎の後䋛䩲帯骨化は, 一般に頻度は少なく, 臨床 的に無症状のものも多いために, その ${ }^{5)}$ 臨床的意義につ いては, 従来あまり注目されていなかった。しかし， 今回の椎間板へルニアの症例のごとく, 後縦䩲帯骨化 が直接的に症状に関与していないとしても，間接的に 関与したかも知れないと考えられる症例もみられ，さ らに今回の調査からも後縦靱帯骨化が腰部の局所症状 にも，少なからず影響をもたらしているとの印象を持 っており, 注意深く観察すれば, 腰椎後緃䩚帯骨化も, かなりの確率で症状の発現に関与しうるものと考えら れる。

\section{結語}

1. 下肢症状を認めた腰椎後縦靱帯骨化 8 例につい て, X線学的, 臨床的検討を行った。

2. 臨床症状と補助検査所見から, 症状が後縌勒帯 骨化に起因する腰椎後縦鞅帯骨化症 5 例と, 後緃勒帯 骨化の関与は少ない椎間板へルニアの 3 例に分類でき
た

3.X線上, 腰椎後縦勒带骨化症例は, 椎間板へル ニア例に比し, 後緃勒帯骨化は大きく春柱管狭窄率も 高かった.

4. 腰椎後縦靱帯骨化は, 無症候性のものも多く明 らかな神経症状を呈すことは少ないが注意深い観察が 必要である。

\section{参 考 文 献}

1）小田裕胤，河合伸也：骨形成的椎弓切除術. 整形外 科 Mook, $41: 251-264,1985$.

2）河合伸也, 服部 奨, 小田裕涓：腰部脊柱管狭窄症 の臨床症状. 整形外科, $32: 720-726,1981$.

3）河合伸也, 服部 奨, 早川 宏 - 他：腰部脊柱管狭 窄に対する骨形成的椎管拡大術. 西日本脊椎研究会誌, $5: 162-168,1979$.

4）服部 奨, 河合伸也：腰部脊椎管狭窄に対する腰椎 椎管拡大術. 整形外科 Mook, $11: 166-173,1979$.

5）三浦幸雄, 今給黎篤弘, 南郷俊明・他：腰椎部 OPLL の基礎的ならびに臨床的研究. 厚生省特定疾患, 骨・ 䨣帯異常調查研究班. 昭和 54 年度研究報告書：104120,1980 . 